\title{
High mobility group box 1 potentiates the pro-inflammatory effects of interleukin- $1 \beta$ in osteoarthritic synoviocytes
}

Isabel García-Arnandis ${ }^{1}$, Maria Isabel Guillén ${ }^{1,2}$, Francisco Gomar ${ }^{3}$, Jean-Pierre Pelletier ${ }^{4}$, Johanne Martel-Pelletier ${ }^{4}$, Maria José Alcaraz ${ }^{1 *}$

\begin{abstract}
Introduction: High mobility group box 1 (HMGB1) is released by necrotic cells or secreted in response to inflammatory stimuli. Extracellular HMGB1 may act as a pro-inflammatory cytokine in rheumatoid arthritis. We have recently reported that $\mathrm{HMGB1}$ is released by osteoarthritic synoviocytes after activation with interleukin-1 beta (IL$1 \beta$ ) The present study investigated the role of HMGB1 in synovial inflammation in osteoarthritis (OA).

Methods: HMGB1 was determined in human synovium using immunohistochemistry, comparing normal to OA. OA synoviocytes were incubated with HMGB1 at 15 or $25 \mathrm{ng} / \mathrm{ml}$ in the absence or presence of IL-1 $\beta(10 \mathrm{ng} / \mathrm{ml})$. Gene expression was analyzed by quantitative PCR and protein expression by Western Blot and ELISA. Matrix metalloproteinase (MMP) activity was studied by fluorometric procedures and nuclear factor (NF)- $\kappa$ B activation by transient transfection with a NF- $\kappa$ B-luciferase plasmid.

Results: In the normal synovium, HMGB1 was found in the synovial lining cells, sublining cells, and in the vascular wall cells. The distribution of HMGB1 in OA synovium was similar but the number of HMGB1 positive cells was higher and HMGB1 was also present in infiltrated cells. In normal synovial membrane cells, HMGB1 was found mostly in the nuclei, whereas in OA, HMGB1 was generally found mostly in the cytoplasm. In OA synoviocytes, HMGB1 alone at concentrations of 15 or $25 \mathrm{ng} / \mathrm{ml}$ did not affect the production of IL-6, IL-8, CCL2, CCL20, MMP-1 or MMP-3, but in the presence of IL-1 $\beta$, a significant potentiation of protein and mRNA expression, as well as MMP activity was observed. HMGB1 also enhanced the phosphorylated ERK1/2 and p38 levels, with a lower effect on phosphorylated Akt. In contrast, JNK1/2 phosphorylation was not affected. In addition, HMGB1 at $25 \mathrm{ng} / \mathrm{ml}$ significantly potentiated NF- $\kappa$ B activation in the presence of IL-1 $1 \beta$.
\end{abstract}

Conclusions: Our results indicate that HMGB1 is overexpressed in OA synovium and mostly present in extracellular form. In OA synoviocytes, HMGB1 cooperates with IL-1 $\beta$ to amplify the inflammatory response leading to the production of a number of cytokines, chemokines and MMPs. Our data support a pro-inflammatory role for this protein contributing to synovitis and articular destruction in OA.

\section{Introduction}

The nuclear DNA-binding protein high mobility group box 1 (HMGB1) can be passively released by necrotic cells or secreted by macrophages and other myeloid cells in response to inflammatory stimuli as part of the inflammatory response to infection or injury (reviewed

\footnotetext{
* Correspondence: maria.jalcaraz@uv.es

'Department of Pharmacology, University of Valencia, Av.Vicent Andrés Estellés s/n, Burjasot, 46100 Valencia, Spain

Full list of author information is available at the end of the article
}

in [1]). It is known that pro-inflammatory cytokines such as IL-1 $\beta$ or TNF $\alpha$ stimulate HMGB1 translocation into the cytoplasm and release in different cell types, although TNF $\alpha$ is not the main inducer of extracellular HMGB1 during synovitis in rheumatoid arthritis patients [2]. Oxidative stress has also been shown to induce HMGB1 release potentially through a mitogenactivated protein kinase (MAPK) and chromosome region maintenance mechanism [3].

\section{Biomed Central}

(c) 2010 García-Arnandis et al.; licensee BioMed Central Ltd. This is an open access article distributed under the terms of the Creative Commons Attribution License (http://creativecommons.org/licenses/by/2.0), which permits unrestricted use, distribution, and reproduction in any medium, provided the original work is properly cited. 
There is abundant evidence that HMGB1 induces cell proliferation, migration and differentiation [4-6]. Binding of HMGB1 to bacterial products might create complexes inducing innate immune responses and production of inflammatory mediators. Extracellular HMGB1 interacts with receptor for advanced glycation end products (RAGE) and the toll-like receptors (TLR) including TLR-2 and TLR-4 [1] leading to the activation of monocytes, macrophages and dendritic cells. In addition, the interaction of HMGB1 with phosphatidylserine on the cell surface inhibits the phagocytosis of apoptotic neutrophils by macrophages [7], which may retard the resolution of inflammation. Nevertheless, recent studies suggest that HMGB1 alone demonstrates minor proinflammatory activity, which is potentiated through binding to IL-1 $\beta$ and other inflammatory mediators [8].

HMGB1 plays a role as a pro-inflammatory cytokine in rheumatoid arthritis and animal models of this disease. Hence, HMGB1 is overexpressed in synovial tissue of rheumatoid arthritis patients and its extracellular form has been related to the progression of arthritis in animal models [9]. Moreover, RAGE activation by HMGB1 results in increased invasiveness of fibroblastlike synoviocytes from rheumatoid arthritis patients [10].

In human articular cartilage, HMGB1 may participate in endochondral ossification during osteogenesis [11] and recently, the related protein HMGB2 has been involved in ageing and osteoarthritis (OA) [12]. Studies show that HMGB1 [13] and its receptor RAGE [14] are expressed in OA cartilage. It is also known that stimulation of OA chondrocytes with HMGB1 results in phosphorylation of extracellular signal-regulated kinase (ERK) and nuclear factor $-\kappa \mathrm{B}(\mathrm{NF}-\kappa \mathrm{B})$, and matrix metalloproteinase (MMP) expression [14]. In addition, activation of RAGE by advanced glycation end products (AGEs) in OA chondrocytes and synoviocytes leads to increased catabolic activity and cartilage degeneration [15]. Nevertheless, the pro-inflammatory activity of HMGB1 in synoviocytes and its participation in synovitis during OA remain to be determined. We have recently reported that HMGB1 is released by OA synoviocytes after activation with IL-1 $\beta$ [16], suggesting the participation of HMGB1 in the inflammatory response induced by this cytokine. In the present study, we further investigated the role of HMGB1 in OA synovial inflammation.

\section{Materials and methods}

\section{Specimen selection}

Human OA knee synovial membranes were obtained from patients (12 female, 3 male, aged $69 \pm 1$ years, mean \pm standard error of the mean (SEM)) undergoing total knee arthroplasty. All patients fulfilled the American College of Rheumatology criteria for OA of the knee [17]. Normal knees (2 female, 1 male, aged $72 \pm$ 1.5 years) were obtained within 12 hours of death; the tissues were examined macroscopically and microscopically to ensure that only normal tissue was used. This study was approved by the Institutional Ethical Committee and is in compliance with all ethical standards and patients' consent according to the Declaration of Helsinki.

\section{Immunohistochemistry of HMGB1 in human synovium}

HMGB1 was determined in the human synovium using immunohistochemistry, comparing normal with OA. Tissues were processed following two methodologies. Firstly, we used an HMGB1 antibody that was revealed with 3,3'-diaminobenzidine (DAB) for reading with light microscope, and secondly a fluorescent HMGB1 antibody for fluorescence microscopy analysis. In brief, the specimens were dissected and fixed in TissuFix \#2 (Chaptec, Montreal, QC, Canada) and processed directly after acquisition from the donor for immunohistochemistry (basal synthesis), as previously described [18]. Sections of $5 \mu \mathrm{m}$ of paraffin-embedded specimens were deparaffinized in toluene and rehydrated in a graded series of ethanol. The synovium was treated with Triton $\mathrm{X}-100(0.3 \%)$ for 20 minutes at room temperature. Slides were washed in PBS followed by $3 \%$ hydrogen peroxide/methanol for 15 minutes. They were further incubated for 45 minutes with 1.5\% normal serum (Vector Laboratories, Burlingame, CA, USA) and overlaid with the rabbit anti-human HMGB1 antibody (1:50 dilution; Abcam, Cambridge, MA, USA) for 18 hours at $4^{\circ} \mathrm{C}$ in a humidified chamber. The second antibody was a goat anti-rabbit immunoglobulin (Vector Laboratories, Burlingame, CA, USA) in which slides were incubated for 45 minutes. For reading with a light microscope, slides were stained using the avidin-biotin complex method (Vectastain ABC kit, Vector Laboratories, Burlingame, CA, USA). The colour was developed with DAB (DAKO Diagnostics Canada Inc., Mississauga, ON, Canada) without nickel chloride. The slides were counter-stained with Mayer's hematoxylin. Each section was examined under a light microscope (Leitz Orthoplan; Leica Inc., St-Laurent, QC, Canada) and photographed with a Retega OEM Fast camera (QImaging, Surrey, BC, Canada). For detection with fluorescence of Alexa 488 fluorochrome, slides were stained with TSA $^{\mathrm{TM}}$ \#22 (Invitrogen, Burlington, ON, Canada) and mounted with Vectashield (Vector Laboratories, Burlingame, CA, USA) containing 4',6-diamidino-2-phenylindole (DAPI) in order to stain the nucleus. The slides were examined under a fluorescence microscope and photographed by a CoolSNAP cf Photometrics camera (Roper Scientific, Rochester, NY, USA). Controls were performed to determine the specificity of staining: i) substitution of the 
primary antibodies with non-immune isotype rabbit IgG (used at the same concentration as the primary antibody); ii) immunoadsorbed with 20-fold excess of the peptide HMGB1; and iii) omission of primary antibody. Controls showed only background staining.

The presence of the antigen in the synovium was quantified by determining the number of cells that stained positive with the distinction between nuclear and extra-nuclear (cytoplasmic and cell vicinity) staining. Each synovial membrane was divided into three microscopic fields (40x; Leitz Orthoplan) and the total number of cells and those staining positive for the specific antigen were determined in the lining cells for both normal and OA, and in the infiltrates for OA specimens. The final results were expressed as the percentage of cells staining positive for the antigen with the maximum score being $100 \%$.

Moreover, the synovial lining cell hyperplasia was graded on a scale of 0 to 2 as previously described [19], where $0=1$ to 2 layers of cells, $1=3$ to 5 layers, and 2 $=6$ or more layers. The layers were counted from the surface of the membrane to the subsynovial tissue. Each synovium was graded into three microscopic fields (40x; Leitz Orthoplan) and the score averaged.

\section{Confocal microscopy}

Discrimination of the HMGB1 location within the cells was confirmed using immunofluorescence followed by confocal microscopy. In brief, sections of $10 \mu \mathrm{m}$ of paraffin-embedded specimens were treated as above. Confocal acquisitions were carried out with a Leica TCS SP5 broadband confocal microscope (St-Laurent, QC, Canada, which uses confocal point-scanning for optical sectioning. In addition, it has a spectral imaging detector allowing tunable emission bands and dye separation. The system is equipped with the AOBS (Acousto-Optical Beam Splitter) for optical beam splitting. It has three lasers: Ar 458/488/514, DPSS 561 and HeNe 633, 543, 594.

\section{Cell culture and treatments}

Synovial specimens were finely minced and isolated by enzymatic digestion with collagenase type 1A (Sigma Aldrich, St Louis, MO, USA) in DMEM/HAM F12 (Sigma-Aldrich, St Louis, MO, USA) containing penicillin $(100 \mathrm{U} / \mathrm{ml})$ and streptomycin $(100 \mu \mathrm{g} / \mathrm{ml})$ at $37^{\circ} \mathrm{C}$ in $5 \%$ carbon dioxide atmosphere for 16 hours. The digested tissue was filtered through a $70 \mathrm{~mm}$ nylon mesh, washed and centrifuged. Cell viability was greater than $95 \%$ according to the Trypan blue exclusion test. Collected cells were resuspended in DMEM/HAM F12 (Sigma-Aldrich, St Louis, MO, USA) containing penicillin $(100 \mathrm{U} / \mathrm{ml})$ and streptomycin $(100 \mu \mathrm{g} / \mathrm{ml})$ supplemented with $10 \%$ fetal bovine serum (Sigma-Aldrich, St
Louis, MO, USA) and cultured at $37^{\circ} \mathrm{C}$ in $5 \%$ carbon dioxide atmosphere until third passage (95\% fibroblasts, detected by immunocytochemistry with anti-collagen I antibody (Chemicon, Millipore Iberica, Madrid, Spain)). Synoviocytes were allowed to grow to nearly confluence and incubated with HMGB1 (HMGBiotech, Milano, Italy) at 15 or $25 \mathrm{ng} / \mathrm{ml}$ and IL- $1 \beta(10 \mathrm{ng} / \mathrm{ml}$, Peprotech EC Ltd, London, UK) or culture medium. Viability studies were performed for all the experimental conditions. None of the treatments significantly affected cell viability which was more than $90 \%$ as tested by Trypan blue exclusion. The possibility of endotoxin contamination of HMGB1 was excluded after performing the Limulus test using the commercial kit from Sigma-Aldrich (St Louis, MO, USA; data not shown).

\section{Western blot analysis}

After stimulation for five minutes with IL-1 $\beta$ (10 ng/ $\mathrm{ml})$, HMGB1 at 15 and $25 \mathrm{ng} / \mathrm{ml}$ or IL- $1 \beta+$ HMGB1, synoviocytes were lysed in $100 \mu \mathrm{l}$ of buffer (1\% Triton $\mathrm{X}-100,1 \%$ deoxycholic acid, $20 \mathrm{mM} \mathrm{NaCl}$ and $25 \mathrm{mM}$ Tris, $\mathrm{pH}$ 7.4) and centrifuged at $4^{\circ} \mathrm{C}$ for 15 minutes at $10,000 \mathrm{~g}$. Proteins $(25 \mu \mathrm{g})$ in cell lysates were separated by $12.5 \%$ SDS-PAGE and transferred onto polyvinylidene difluoride membranes. Membranes were blocked with $3 \%$ bovine serum albumin and incubated with specific antibodies against phosphorylated ERK (Cell Signaling Technology, Inc., Beverly, MA, USA, dilution 1:800), phosphorylated or total Akt and ERK (Cell Signaling Technology, Inc., Beverly, MA, USA; dilution 1:500), and phosphorylated or total c-Jun Nterminal kinase (JNK; Cell Signaling Technology, Inc., Beverly, MA, USA; dilution 1:250) and p38 (Promega Corporation, Madison, WI, USA; dilution 1:250) overnight at $4^{\circ} \mathrm{C}$. Finally, membranes were incubated with peroxidase-conjugated goat anti-rabbit IgG (Dako, Copenhagen, Denmark) and the immunoreactive bands were visualized by enhanced chemiluminescence (GE Healthcare, city, Barcelona, Spain) using the AutoChemi image analyzer (UVP Inc., Upland, CA, USA).

\section{Determination of MMP activity}

Cells were stimulated with IL-1 $\beta$ (10 ng/ml), HMGB1 at 15 and $25 \mathrm{ng} / \mathrm{ml}$ or IL-1 $\beta+$ HMGB1 for 24 hours and supernatants were harvested, centrifuged and incubated with p-aminophenyl mercuric acetate for six hours at $37^{\circ} \mathrm{C}$ to activate MMPs. Aliquots of supernatants were then transferred to a 96-well plate and after addition of the 5-FAM peptide substrate (AnaSpec Inc., San Jose, CA, USA), fluorescence was measured for different times at $490 \mathrm{~nm}$ (excitation)/520 $\mathrm{nm}$ (emission) in a Victor3 microplate reader (PerkinElmer España, Madrid, Spain). 


\section{Enzyme-linked immunosorbent assay}

Synoviocytes were stimulated with IL-1 $\beta$ (10 ng/ml) for 24 hours, in the presence or absence of HMGB1 at 15 and $25 \mathrm{ng} / \mathrm{ml}$. Supernatants were harvested, centrifuged and frozen at $-80^{\circ} \mathrm{C}$ until analysis. IL-6, IL-8 and chemokine ( $\mathrm{C}-\mathrm{C}$ motif) ligand 2 (CCL2) levels were determined by specific ELISA from eBioscience (San Diego, CA, USA) with sensitivity of 2,4 and $7 \mathrm{pg} / \mathrm{ml}$, respectively. CCL20 was determined with a specific ELISA from Raybiotech Inc. (Norcross, GA, USA) with sensitivity of $1.5 \mathrm{pg} / \mathrm{ml}$. MMP-1 and MMP-13 protein was quantified in supernatants by using specific ELISAs from AnaSpec (sensitivity of 8 and $6 \mathrm{pg} / \mathrm{ml}$, respectively), and MMP-3 with the ELISA from Raybiotech Inc. (sensitivity of $0.3 \mathrm{ng} / \mathrm{ml}$ ).

\section{Real-time PCR}

Following incubation for 24 hours, total RNA was extracted using the TriPure reagent (Roche Applied Science, Barcelona, Spain) according to the manufacturer's instructions. Reverse transcription was accomplished on $1 \mu \mathrm{g}$ of total RNA using random primers (TaqMan reverse transcription reagents, Applied Biosystems, Spain, Madrid). PCR assays were performed in duplicate on an iCycler Real-Time PCR Detection System using SYBR Green PCR Master Mix (Bio-Rad Laboratories, Richmond, CA, USA) [20]. Sequences of primers used have been reported previously [21-24]. For each sample, differences in threshold cycle $\left(\mathrm{DC}_{\mathrm{t}}\right)$ values were calculated by correcting the $C_{t}$ of the gene of interest to the $C_{t}$ of the reference gene glyceraldehide3-phosphate dehydrogenase. Relative gene expression was expressed as DDCt with respect to nonstimulated cells.

\section{Activation of NF- $\kappa$ B}

Cells were seeded into six-well plates and grown to 50 to $60 \%$ confluence. Transient transfection was performed for 45 minutes with $2 \mu \mathrm{g}$ of the reporter construct NF- $\kappa$ B-luc (Stratagene, La Jolla, CA, USA) and 1 $\mu \mathrm{g}$ of the internal control pRL-TK (Promega Corporation, Madison, WI, USA) by the Magnetofection ${ }^{\mathrm{TM}}$ system (OZ Biosciences, Marseille, France) according to the manufacturer's recommendations. The medium was then replaced and cells were treated for 24 hours with HMGB1 at $25 \mathrm{ng} / \mathrm{ml}$ in the absence or presence of IL-1 $\beta(10 \mathrm{ng} / \mathrm{ml})$. After lysis and centrifugation, aliquots of supernatants were used to assay firefly and Renilla luciferase activity using the Dual-Luciferase Reporter Assay System kit (Promega Corporation, Madison, WI, USA). Luminescence was measured in a Microbeta counter (Wallac, Turku, Finland) and firefly luciferase activity was normalized to Renilla luciferase activity.

\section{Statistical analysis}

Results are presented as mean \pm SEM. Statistical analyses were performed using one-way analysis of variance followed by Dunnett's $t$-test for multiple comparisons and two-tailed unpaired Student's $t$-test for dual comparisons.

\section{Results}

\section{HMGB1 expression in human synovium}

In the normal and OA synovium, HMGB1 was found in the cells of the synovial lining, sublining cells, and in the cells of the vascular wall (i.e. cells around the blood vessels) (Figure 1a). We further performed an analysis of the percentage of positive synoviocytes in the nuclear and extra-nuclear (cytoplasmic and cell vicinity) compartments of the cells comparing normal $(n=3)$ with OA $(n=3)$. As illustrated in Figure $1 \mathrm{~b}$, a statistically significant decrease in HMGB1 was found in OA cell nuclei when compared with normal $(P<0.03)$, and, although there was more positive staining in the extranuclear (cytoplasm and in the cell vicinity) compartment, this did not quite reach statistical significance $(P$ $<0.07)$. In OA synovium, the percentage of infiltrate cells staining positive in the nuclei $(23.6 \pm 3.9 \%)$ was significantly less than in the extra-nuclear compartment $(52.4 \pm 4.1 \% ; P<0.007)$. Moreover, comparison of the synovial lining layers showed, as expected, more cell layers in the OA (score:1.3 \pm 0.2 ) than in the normal $(0.6 \pm 0.2)$ synovial membrane.

Experiments performed with the fluorescent antibody (Figure 2) confirmed that in normal synovial membrane cells, HMGB1 (green) was found mostly in the nuclei with some cells showing cytoplasm staining (Figures 2a to $2 \mathrm{c}$ ). In OA (Figures $2 \mathrm{~b}$ to $2 \mathrm{~d}$ ), however, HMGB1 was generally found mostly in the cytoplasm. For cell infiltrates (Figures 2e to 2f), the pattern was as for the OA lining cells, in which HMGB1 was found mostly in the cytoplasm.

\section{Effect of HMGB1 on cytokine and chemokine production induced by IL-1 $\beta$ in OA synoviocytes}

To determine whether extracellular HMGB1 can modulate cytokine and chemokine production in human $\mathrm{OA}$ synoviocytes, cells were incubated with HMGB1 in the presence or absence of IL-1 $\beta(10 \mathrm{ng} / \mathrm{ml})$. This proinflammatory cytokine is present in OA synovial fluid and cartilage and participates in joint degradation $[25,26]$. As expected, stimulation with IL-1 $\beta$ resulted in the enhanced production of pro-inflammatory cytokines and chemokines. As shown in Figure (3a to $3 \mathrm{~d}$ ), although HMGB1 alone at concentrations of 15 or 25 $\mathrm{ng} / \mathrm{ml}$ did not affect the production of IL-6, IL-8, CCL2 or CCL20, a significant potentiation of these pro-inflammatory mediators was observed in the presence of IL- 


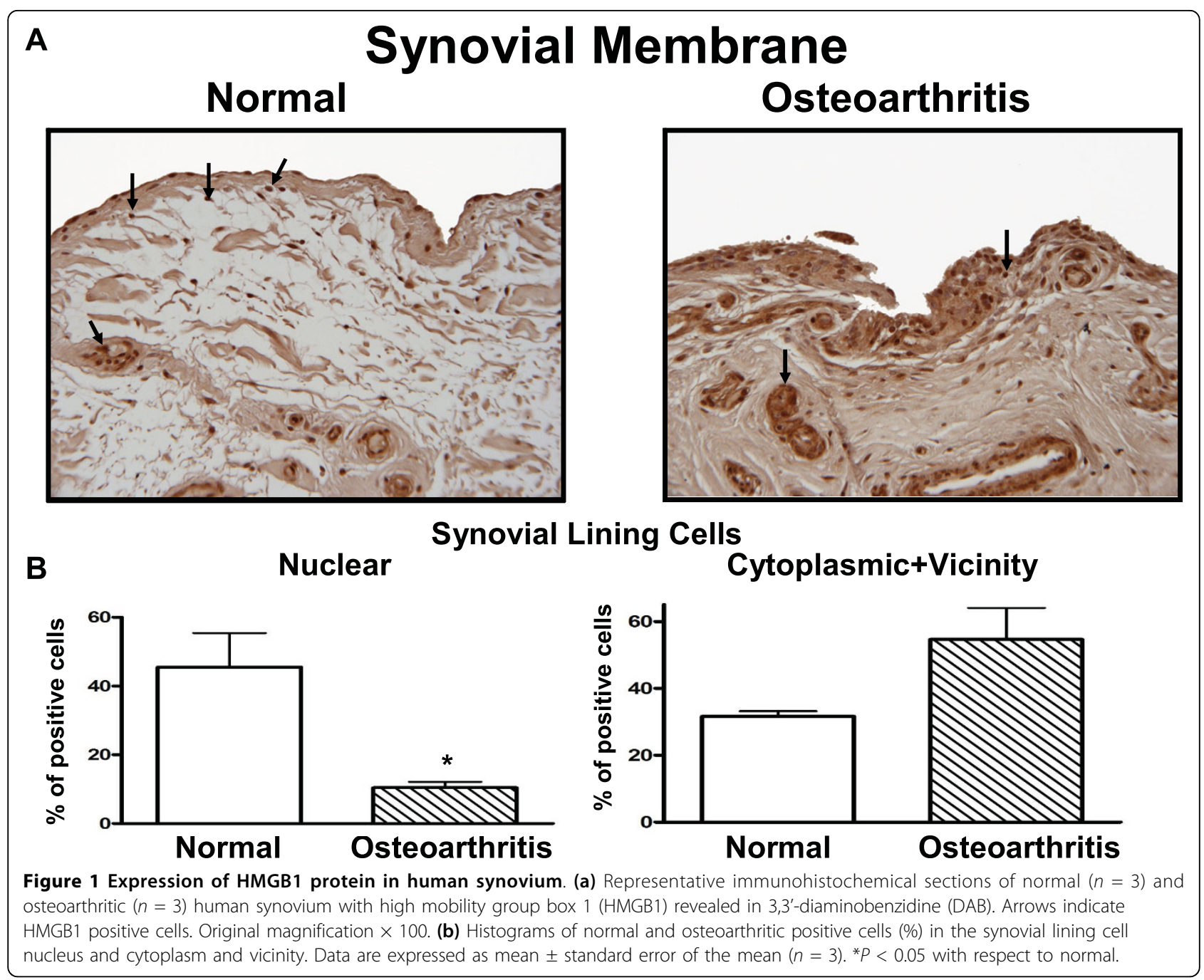

$1 \beta$. These effects of HMGB1 were confirmed at the mRNA level, with an enhancement of IL-6, IL-8, CCL2 and CCL20 mRNA expression in cells stimulated with IL-1 $\beta$ (Figures $4 \mathrm{a}$ and $4 \mathrm{~b}$ ).

\section{Effect of HMGB1 on MMPs induced by IL-1 $\beta$ in OA synoviocytes}

Cell activation by IL- $1 \beta(10 \mathrm{ng} / \mathrm{ml})$ potently induced MMP gene expression as well as MMP protein and activity. mRNA expression was measured by real-time PCR. In cell supernatants, protein levels were measured by ELISA and MMP activity by a fluorometric procedure. As shown in Figure (5a to 5c), HMGB1 alone did not induce significant changes in MMP-1, MMP-3 or MMP-13 protein in cell supernatants, but it potentiated the stimulating effect of IL-1 $\beta$ for MMP-1 and MMP-3. In addition, HMGB1 significantly increased MMP-1 and MMP-3 mRNA expression in the presence of IL-1 $\beta$ (Figure 6a). These effects were reflected in the levels of
MMP activity released into the medium, which were significantly increased by HMGB1 after IL-1 $\beta$ stimulation (Figure 6b).

\section{Effect of HMGB1 on Akt and MAPK phosphorylation induced by IL-1 $\beta$ in OA synoviocytes}

To determine the possible mechanism of action of HMGB1, we further examined whether this protein acts on Akt and MAPK activation. The time of stimulation for a high phosphorylation response was chosen from previous experiments [see Additional file 1]. As shown in Figure 7, HMGB1 at both concentrations studied (15 and $25 \mathrm{ng} / \mathrm{ml}$ ) increased the phosphorylated Akt and ERK1/2 levels. In the presence of IL-1 $\beta$, HMGB1 enhanced the phosphorylated ERK1/2 and p38 levels, with a lower effect on phosphorylated Akt. In contrast, JNK $1 / 2$ phosphorylation was not affected by HMGB1 either in the presence or absence of IL-1 $\beta$ stimulation. 


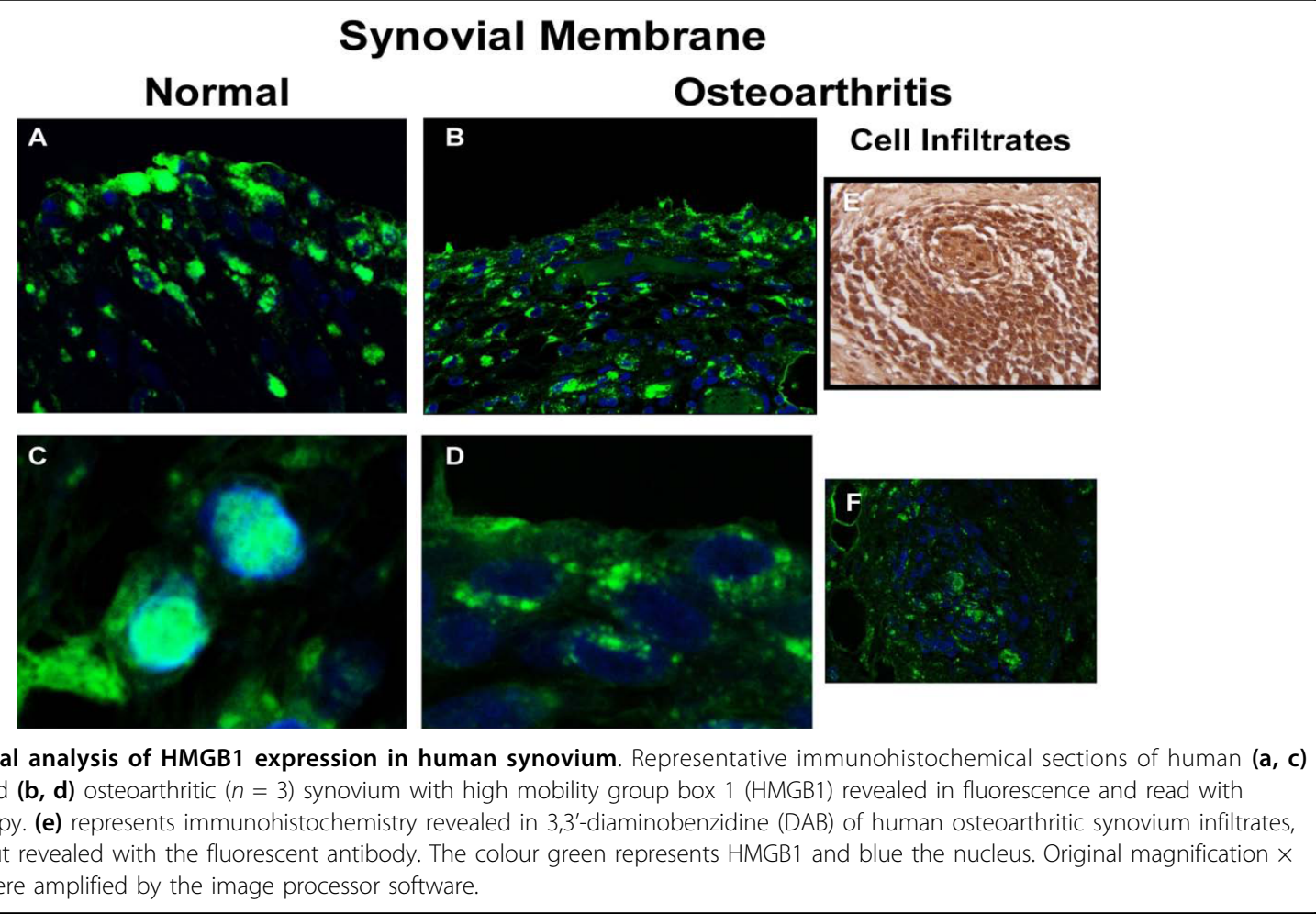

Effect of HMGB1 on NF- $\kappa$ B activation induced by IL-1 $\beta$ in OA synoviocytes

$\mathrm{NF}-\kappa \mathrm{B}$ is a main regulator of pro-inflammatory and degradative genes in the joint. As IL-1 $\beta$ [27] and HMGB1 [28] cell stimulation results in the activation of this pathway in different cell types, we studied the possible participation of this mechanism in the pro-inflammatory effects of HMGB1 in OA synoviocytes. HMGB1 treatment in nonstimulated cells resulted in increased transcriptional activity, although it did not reach statistical significance. Of note, HMGB1 at $25 \mathrm{ng} / \mathrm{ml}$ significantly potentiated NF- $\kappa \mathrm{B}$ activation in the presence of IL-1 $\beta$ (Figure 8).

\section{Discussion}

Synovial inflammation has been demonstrated in tissue samples of OA patients and may be related to disease progression $[17,29,30]$. Several lines of evidence support the involvement of synoviocytes in OA cartilage degradation through the production of inflammatory and catabolic mediators [31]. In this regard, pro-inflammatory cytokines such as IL- $1 \beta$ play a role in driving synovitis during $\mathrm{OA}$ and influencing the production of cytokines and MMPs [32]. With respect to the biological role of HMGB1, it is essential to understand the mechanisms involved in the regulation of the inflammatory response. HMGB1 appears to act as a pro-inflammatory cytokine in mononuclear cells through the release of TNF $\alpha$, IL-1 $\beta$, IL-6, IL-8, macrophage inflammatory protein -1 and nitric oxide $[4,33]$. In addition, HMGB1 stimulates the motility of a wide range of cells and thus elicits the migration to the site of tissue damage, a process dependent on the activation of ERK, NF- $\kappa$ B [34] and Src [35] pathways.

Our data first showed that less HMGB1 is observed in the nuclei of OA synoviocytes, and although a higher level is found in the cytoplasm and vicinity in these cells, this did not quite reach statistical significance. This lack of significance could be related to the low number of specimens analysed; however, as HMGB1 is released extra-cellularly, our evaluation could be falsely lower. Yet, as there were more cell layers in OA compared with normal, in addition to the presence of cell infiltrates in OA showing an elevated level of HMGB1 in the extra-nuclear compartment compared with the nuclear, this strongly suggests that more HMGB1 is released from OA synovial cells than from normal, supporting the previous data in which OA cells released HMGB1 upon activation by IL-1 $\beta$ [16]. We thus hypothesized that HMGB1 may play a role in modulating the inflammatory process in synovium during OA. Our results indicate that HMGB1 cooperates with IL-1 $\beta$ to amplify the inflammatory response leading to the production of a number of cytokines, chemokines and MMPs in OA synoviocytes. Data showed that HMGB1 plus IL-1 $\beta$ synergistically 


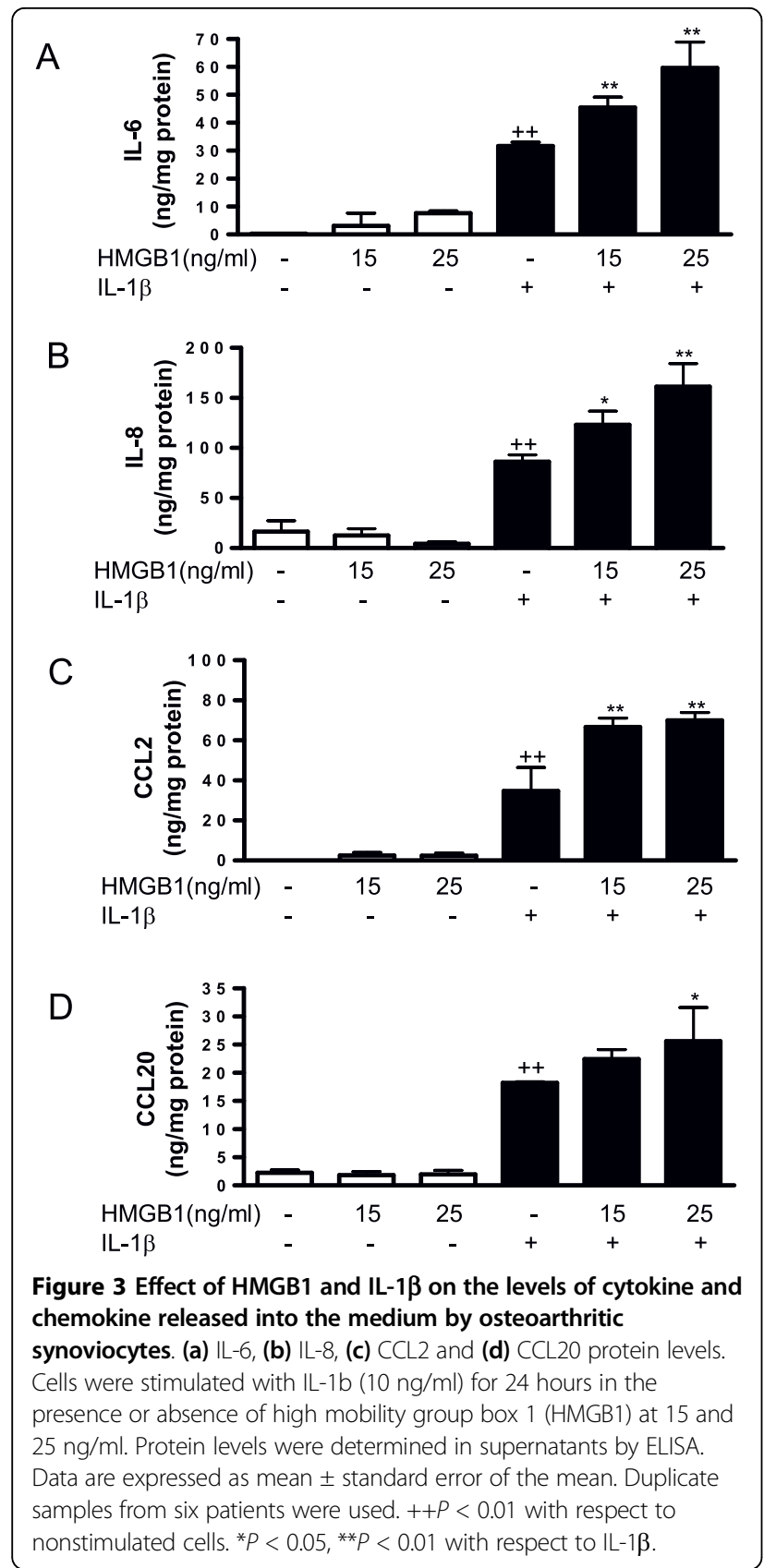

enhanced IL- 6 production, which is in line with a recent report on the stimulation of IL- 6 release by preformed complexes of HMGB1 $(100 \mathrm{ng} / \mathrm{ml})$ and IL-1 $\beta$ at a low concentration unable to stimulate synoviocytes $(0.05 \mathrm{ng} / \mathrm{ml})$. Interestingly, the response of synovial fibroblasts from OA or rheumatoid arthritis patients was similar [36].

Chemokines such as IL-8, CCL2 and CCL20 are produced by OA synoviocytes, but to a lower extent than rheumatoid arthritis cells. These mediators have the ability to attract inflammatory cells and regulate gene

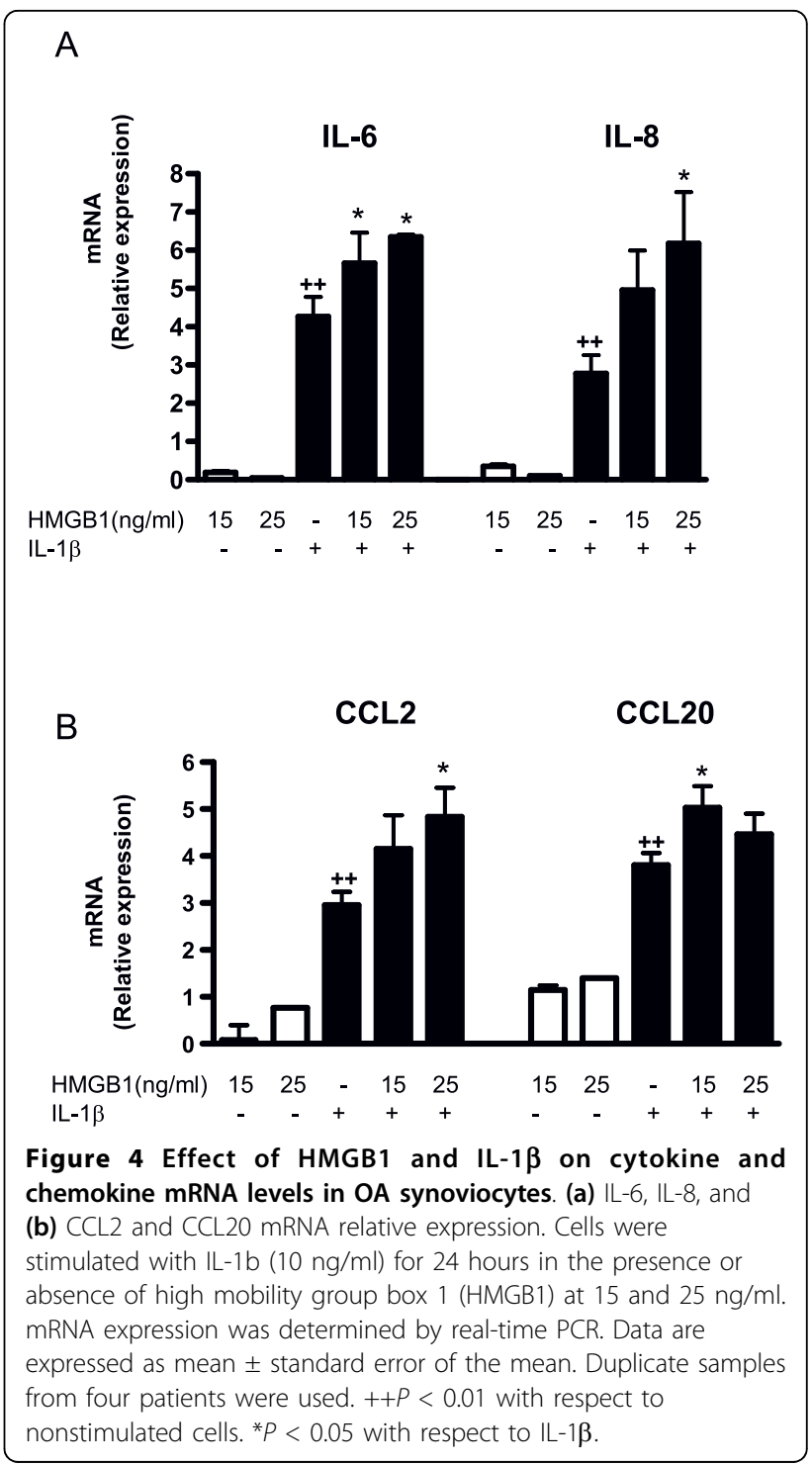

transcription and cell proliferation [37]. The up-regulation of chemokines upon IL- $1 \beta$ synoviocyte stimulation promotes inflammation and cartilage degradation through the activation of MMPs and other degradative enzymes [38]. CCL2 and CCL20 are chemokines implicated in rheumatoid arthritis synovitis [39-41] and are produced by OA synovium in the presence of pro-inflammatory cytokines. In particular, IL- $1 \beta$ has been shown to be a more potent inducer of CCL20 than TNFa or IL-17 [42]. Our data revealed that HMGB1 acted on OA synoviocytes in vitro to enhance the production of IL-8, CCL2 and CCL20. The best studied CXC chemokine is IL-8, which is produced by fibroblasts and macrophages present in synovial tissues [43]. Induction of synovial macrophage and fibroblast chemotaxis has been demonstrated for CCL2 [40,44], whereas CCL20 induces monocyte and 


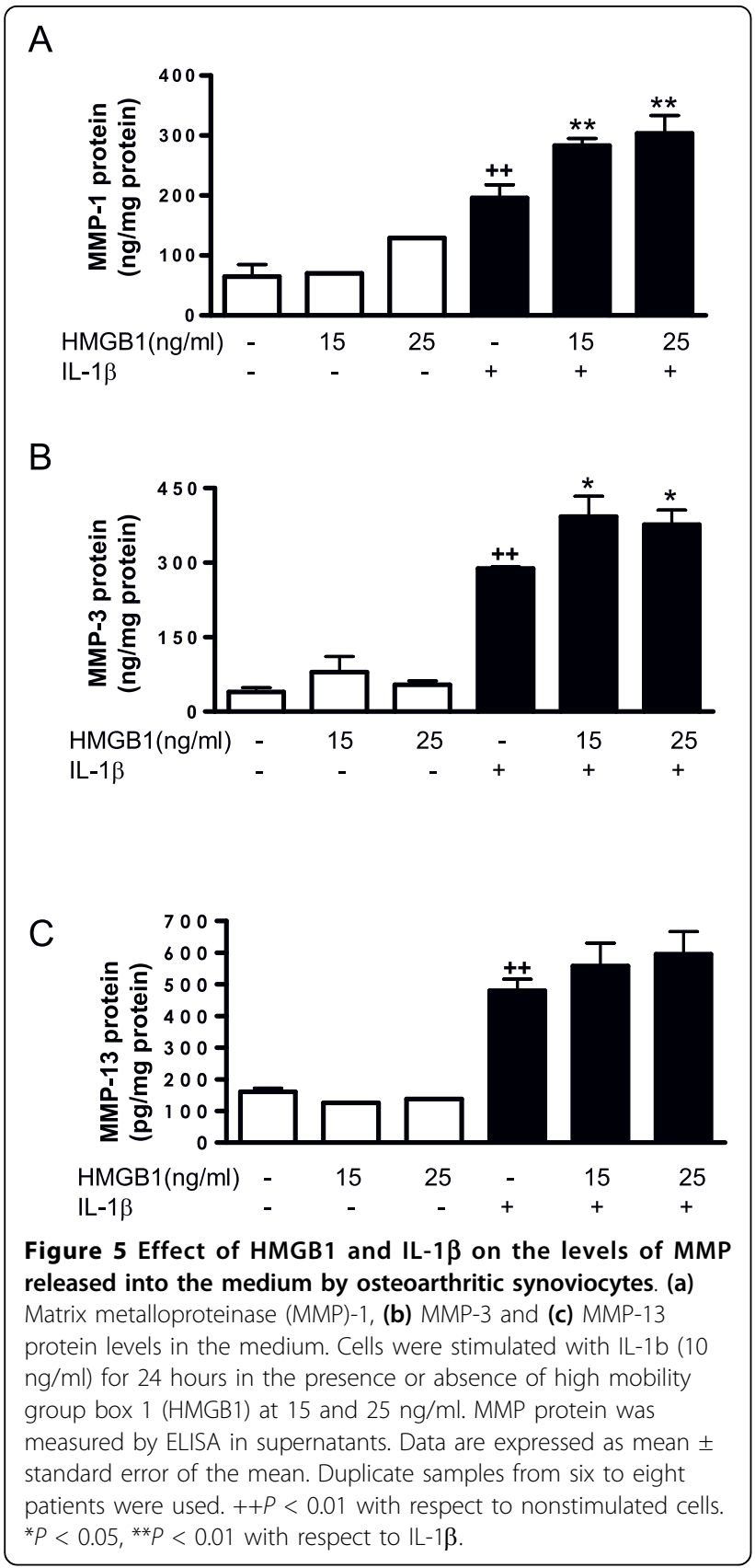

memory lymphocyte chemotaxis from peripheral blood to the rheumatoid joint [45]. Therefore, the enhanced production of these mediators in the presence of HMGB1 supports a role for this protein in the amplification of the inflammatory response induced by IL- $1 \beta$ in OA synoviocytes.

MMPs play an important role in articular tissue degradation in OA. The present study demonstrated the potentiating effect of HMGB1 on IL-1 $\beta$ induction of MMP-1 and MMP-3 in human OA synoviocytes. As MMP-1 degrades collagens in the extracellular matrix [46-48] and MMP-3 activity leads to activation of collagenases [49],

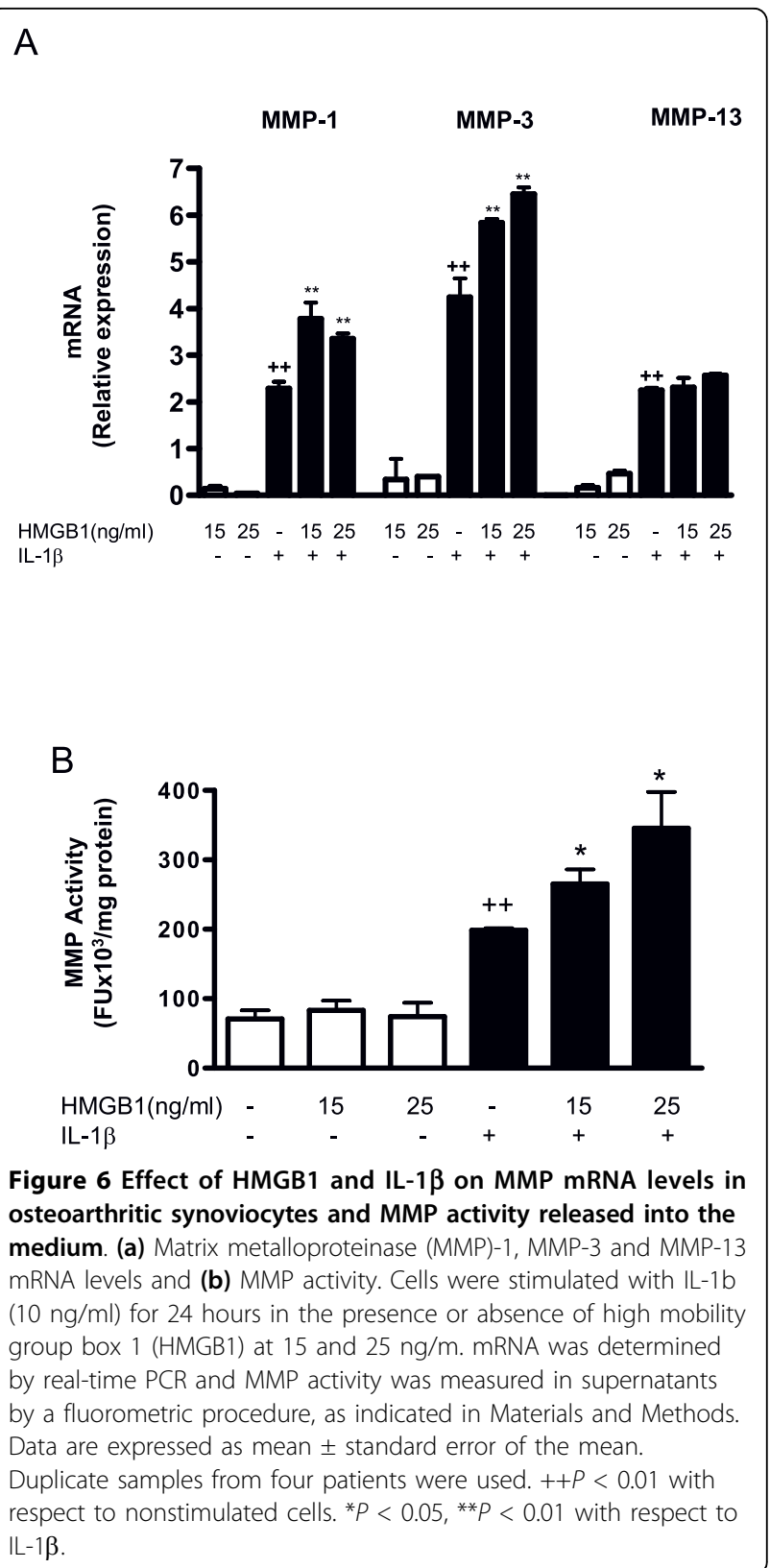

our results suggest the amplification of catabolic responses by HMGB1 during joint inflammation.

Several studies indicate that spontaneous or stimulated production of many inflammatory and degradative mediators by OA synoviocytes are related to NF- $\kappa \mathrm{B}$ activation [50,51]. In particular, transcription of IL-6 [52], IL-8 [53], CCL2, CCL20 [41,54] and MMPs [55,56] is NF- $\kappa$ B dependent. Our data show that IL- $1 \beta$ plus HMGB1 synergistically increased the transcriptional activity of NF- $\kappa \mathrm{B}$, leading to an enhanced production of inflammatory and catabolic mediators.

MAPK activity regulates the activation of transcription factors relevant in inflammatory responses [57]. We 


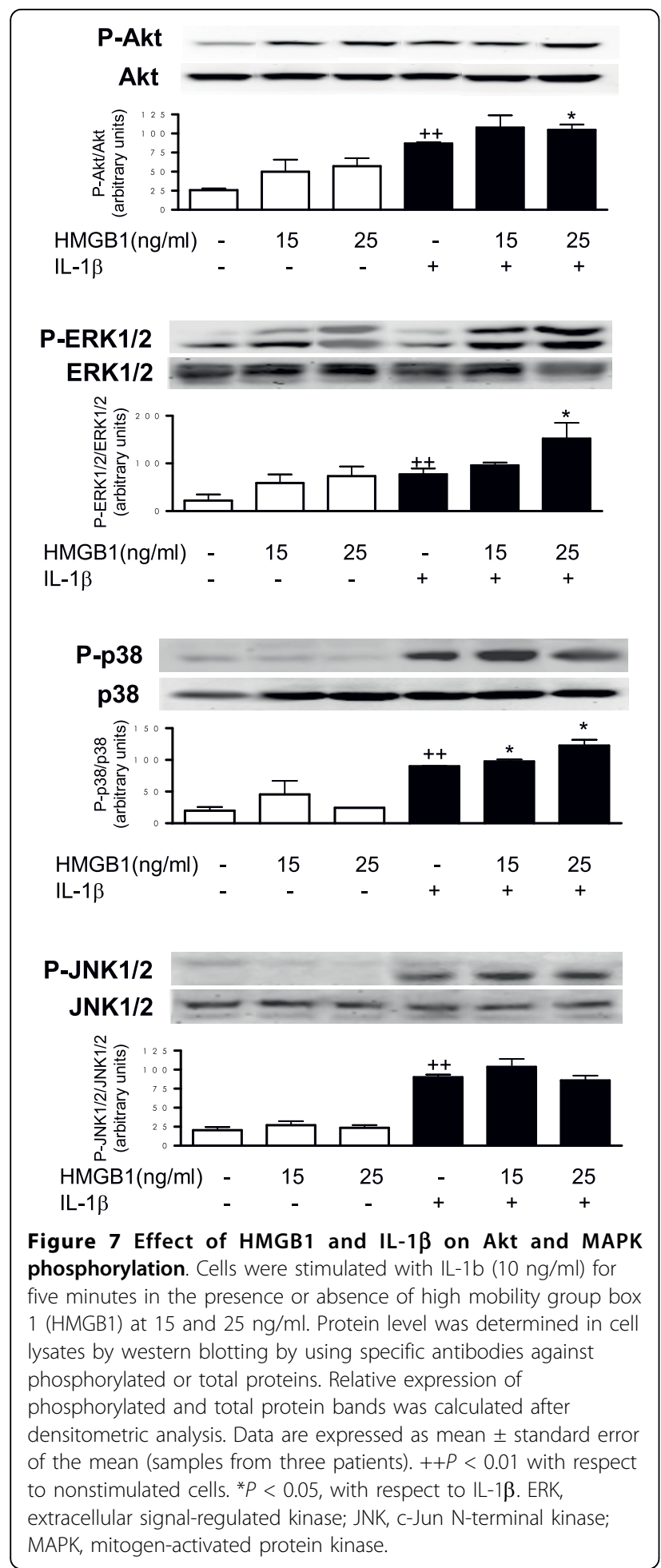

have shown that HMGB1 enhances p38 phosphorylation, which participates in IL- 6 and IL-8 transcription in human fibroblast-like synoviocytes $[58,59]$. As the production of MMP-1 and MMP-3 upon stimulation of synoviocytes with IL-1 $\beta$ depends on ERK activation [60],

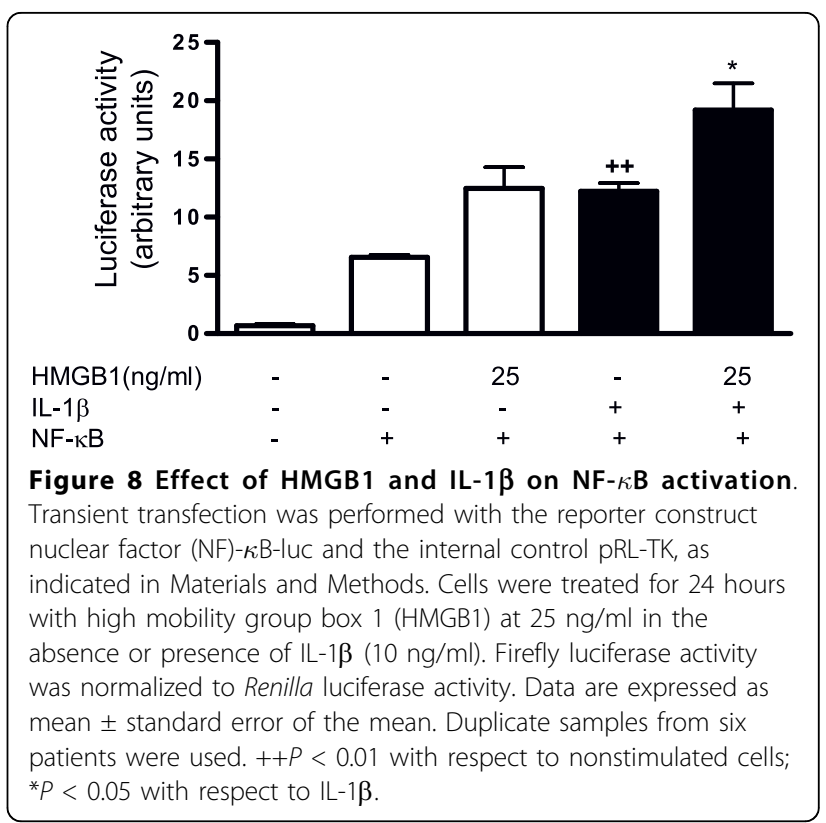

we investigated the effects of HMGB1 on ERK phosphorylation. Our results indicate that HMGB1 potentiates the effects of IL-1 $\beta$ on ERK phosphorylation, which may play a role in the up-regulation of MMP-1 and MMP-3 by HMGB1. In contrast, we did not observe any modification of JNK1/2, which phosphorylates c-Jun and regulates the transcription factor activating protein-1 [61] as well as erythroblastosis 26 transcription factors [62]. Interestingly, HMGB1 potentiates Akt phosphorylation by IL-1 $\beta$, a pathway involved in cell survival and proliferation of fibroblasts in rheumatoid arthritis synovium [63]. In addition, Akt activation may play a role in human cartilage breakdown, because it has been implicated in MMP-13 and aggrecanase-1 expression induced by oncostatin $M$ [64] and the synergistic induction of MMP-1 and MMP-13 expression after oncostatin M $+\mathrm{IL}-1 \beta$ stimulation of human chondrocytes [65]. Our data would therefore suggest that the potentiation of ERK, p38 and Akt activation by HMGB1 may be a mechanism relevant for the increase in the intensity and persistence of synovitis as well as the expression of catabolic factors in OA.

\section{Conclusions}

HMGB1 is overexpressed in synovial membranes of OA patients. The results presented here support the view that HMGB1 would act as a pro-inflammatory cytokine, which enhances the OA synovial inflammatory process. HMGB1 was found to synergize with IL- $1 \beta$ to induce phosphorylation of ERK1/2, p38 and Akt, as well as NF- $\kappa$ B activation. These effects result in the production of pro-inflammatory and catabolic mediators that would contribute to synovitis and articular destruction during OA. 


\section{Additional material}

Additional file 1: Supplementary figure S1. Time course of high mobility group box 1 (HMGB1) and IL-1 $\beta$ effects on Akt and mitogenactivated protein kinase (MAPK) phosphorylation.

\begin{abstract}
Abbreviations
AGE: advanced glycation end product; $C C L$ : chemokine (C-C motif) ligand; DAB: 3,3'-diaminobenzidine; DAPI: 4',6-diamidino-2-phenylindole; ELISA: enzyme-linked immunosorbent assay; ERK: extracellular signal-regulated kinase; HMGB1: high mobility group box 1; IL: interleukin; JNK: c-Jun Nterminal kinase; MAPK: mitogen-activated protein kinase; MMP: matrix metalloproteinase; NF- $\kappa \mathrm{B}$ : nuclear factor- $\kappa \mathrm{B}$; OA: ostearthritis; PBS: phosphate-buffered saline; PCR: polymerase chain reaction; RAGE: receptor for advanced glycation end products; SEM: standard error of the mean; TLR: toll-like receptor; TNF $\alpha$ : tumor necrosis factor- $\alpha$.
\end{abstract}

\section{Acknowledgements}

The authors are grateful to Martin Boily and Christelle Boileau, PhD, from the Osteoarthritis Research Unit, University of Montreal Hospital Research Centre (CRCHUM, Montréal, Québec, Canada), for their expertise in immunohistochemistry and confocal microscopy. This work was supported by grants SAF2007-61769 and RETICEF RD06/0013/2001 (Spanish Ministery of Science and Innovation+FEDER). I. García-Arnandis thanks Generalitat Valenciana for a fellowship.

\section{Author details}

${ }^{1}$ Department of Pharmacology, University of Valencia, Av.Vicent Andrés Estellés s/n, Burjasot, 46100 Valencia, Spain. ${ }^{2}$ Department of Chemistry, Biochemistry and Molecular Biology, Cardenal Herrera-CEU University, Av. Seminario s/n, Moncada, 46113 Valencia, Spain. ${ }^{3}$ Department of Surgery, School of Medicine, University of Valencia, Av. Blasco Ibáñez 15, Valencia, 46010 Valencia, Spain. ${ }^{4}$ Osteoarthritis Research Unit, University of Montreal Hospital Research Centre (CRCHUM), Notre-Dame Hospital, Montreal, 1560 Rue Sherbrooke East, Montreal, Quebec H2L 4M1, Canada.

\section{Authors' contributions}

IG and MIG carried out the experimental work and the data collection and interpretation. FG participated in the design and coordination of experimental work, and acquisition of data. J-PP and JM-P participated in the study design, data collection, analysis of data and preparation of the manuscript. MJA carried out the study design, the analysis and interpretation of data and drafted the manuscript. All authors read and approved the final manuscript.

\section{Competing interests}

The authors declare that they have no competing interests.

Received: 26 January 2010 Revised: 9 July 2010

Accepted: 27 August 2010 Published: 27 August 2010

\section{References}

1. Pisetsky DS, Erlandsson-Harris $H$, Andersson U: High-mobility group box protein 1 (HMGB1): an alarmin mediating the pathogenesis of rheumatic disease. Arthritis Res Ther 2008, 10:209.

2. Sundberg E, Grundtman C, af Klint E, Lindberg J, Ernestam S, Ulfgren AK, Harris HE, Andersson U: Systemic TNF blockade does not modulate synovial expression of the pro-inflammatory mediator HMGB1 in rheumatoid arthritis patients - a prospective clinical study. Arthritis Res Ther 2008, 10:R33.

3. Tang D, Shi Y, Kang R, Li T, Xiao W, Wang H, Xiao X: Hydrogen peroxide stimulates macrophages and monocytes to actively release HMGB1. J Leukoc Biol 2007, 81:741-747.

4. Andersson U, Wang H, Palmblad K, Aveberger AC, Bloom O, ErlandssonHarris $\mathrm{H}$, Janson A, Kokkola R, Zhang M, Yang H, Tracey KJ: High mobility group 1 protein (HMG-1) stimulates proinflammatory cytokine synthesis in human monocytes. J Exp Med 2000, 192:565-570.
5. Dumitriu IE, Bianchi ME, Bacci M, Manfredi AA, Rovere-Querini P: The secretion of $H M G B 1$ is required for the migration of maturing dendritic cells. J Leukoc Biol 2007, 81:84-91.

6. Dumitriu IE, Baruah P, Valentinis B, Voll RE, Herrmann M, Nawroth PP, Arnold B, Bianchi ME, Manfredi AA, Rovere-Querini P: Release of high mobility group box 1 by dendritic cells controls $T$ cell activation via the receptor for advanced glycation end products. J Immunol 2005, 174:7506-7515.

7. Liu G, Wang J, Park YJ, Tsuruta Y, Lorne EF, Zhao X, Abraham E: High mobility group protein-1 inhibits phagocytosis of apoptotic neutrophils through binding to phosphatidylserine. J Immunol 2008, 181:4240-4246.

8. Sha Y, Zmijewski J, Xu Z, Abraham E: HMGB1 develops enhanced proinflammatory activity by binding to cytokines. J Immunol 2008, 180:2531-2537.

9. Andersson $\mathrm{U}$, Erlandsson-Harris $\mathrm{H}$ : HMGB1 is a potent trigger of arthritis. $J$ Intern Med 2004, 255:344-350.

10. Steenvoorden MM, Toes RE, Ronday HK, Huizinga TW, DeGroot J: RAGE activation induces invasiveness of RA fibroblast-like synoviocytes in vitro. Clin Exp Rheumatol 2007, 25:740-742.

11. Taniguchi N, Yoshida K, Ito T, Tsuda M, Mishima Y, Furumatsu T, Ronfani L, Abeyama K, Kawahara K, Komiya S, Maruyama I, Lotz M, Bianchi ME, Asahara $\mathrm{H}$ : Stage-specific secretion of HMGB1 in cartilage regulates endochondral ossification. Mol Cell Biol 2007, 27:5650-5663.

12. Taniguchi N, Carames B, Ronfani L, Ulmer U, Komiya S, Bianchi ME, Lotz M: Aging-related loss of the chromatin protein HMGB2 in articular cartilage is linked to reduced cellularity and osteoarthritis. Proc Natl Acad Sci USA 2009, 106:1181-1186.

13. Attur M, Dave M, Akamatsu M, Nakagawa N, Miki J, Yang H, Katoh M, Wisniewski J, Tracey K, Amin A: Differential expression of high mobility group protein in human normal and arthritic cartilage; Functional genomic analysis. Trans Orthop Res So 2003, 28:18.

14. Loeser RF, Yammani RR, Carlson CS, Chen H, Cole A, Im HJ, Bursch LS, Yan SD: Articular chondrocytes express the receptor for advanced glycation end products: Potential role in osteoarthritis. Arthritis Rheum 2005, 52:2376-2385.

15. Steenvoorden MM, Huizinga TW, Verzijl N, Bank RA, Ronday HK, Luning HA, Lafeber FP, Toes RE, DeGroot J: Activation of receptor for advanced glycation end products in osteoarthritis leads to increased stimulation of chondrocytes and synoviocytes. Arthritis Rheum 2006, 54:253-263.

16. Garcia-Arnandis I, Guillen MI, Castejon MA, Gomar F, Alcaraz MJ: Heme oxygenase-1 down-regulates high mobility group box 1 and matrix metalloproteinases in osteoarthritic synoviocytes. Rheumatology 2010, 49:854-861.

17. Altman R, Asch E, Bloch D, Bole G, Borenstein D, Brandt K, Christy W, Cooke TD, Greenwald R, Hochberg M: Development of criteria for the classification and reporting of osteoarthritis. Classification of osteoarthritis of the knee. Diagnostic and Therapeutic Criteria Committee of the American Rheumatism Association. Arthritis Rheum 1986, 29:1039-1049.

18. Monfort J, Tardif G, Roughley P, Reboul P, Boileau C, Bishop PN, Pelletier JP, Martel-Pelletier J: Identification of opticin, a member of the small leucinerich repeat proteoglycan family, in human articular tissues: a novel target for MMP-13 in osteoarthritis. Osteoarthritis Cartilage 2008, 16:749-755.

19. Pelletier JP, Martel-Pelletier J, Ghandur-Mnaymneh L, Howell DS, Woessner JF Jr: Role of synovial membrane inflammation in cartilage matrix breakdown in the Pond-Nuki dog model of osteoarthritis. Arthritis Rheum 1985, 28:554-561.

20. Guillen Ml, Megias J, Gomar F, Alcaraz MJ: Heme oxygenase-1 regulates catabolic and anabolic processes in osteoarthritic chondrocytes. $J$ Pathol 2008, 214:515-522.

21. Mietz H, Esser JM, Welsandt G, Kociok N, Hueber A, Joussen A, Esser P, Krieglstein GK: Latanoprost stimulates secretion of matrix metalloproteinases in tenon fibroblasts both in vitro and in vivo. Invest Ophthalmol Vis Sci 2003, 44:5182-5188.

22. Boileau C, Pelletier JP, Tardif G, Fahmi H, Laufer S, Lavigne M, MartelPelletier J: The regulation of human MMP-13 by licofelone, an inhibitor of cyclooxygenases and 5-lipoxygenase, in human osteoarthritic chondrocytes is mediated by the inhibition of the p38 map kinase signaling pathway. Ann Rheum Dis 2005, 64:891-898. 
23. Kwon JH, Keates S, Bassani L, Mayer LF, Keates AC: Colonic epithelial cells are a major site of macrophage inflammatory protein 3alpha (MIP3alpha) production in normal colon and inflammatory bowel disease. Gut 2002, 51:818-826.

24. Lockwood CJ, Paidas M, Krikun G, Koopman L, Masch R, Kuczynski E, Kliman H, Baergen RN, Schatz F: Inflammatory cytokine and thrombin regulation of interleukin-8 and intercellular adhesion molecule-1 expression in first trimester human decidua. J Clin Endocrinol Metab 2005, 90:4710-4715

25. Dodge GR, Poole AR: Immunohistochemical detection and immunochemical analysis of type II collagen degradation in human normal, rheumatoid, and osteoarthritic articular cartilages and in explants of bovine articular cartilage cultured with interleukin 1. J Clin Invest 1989, 83:647-661.

26. van der Kraan PM, van den Berg WB: Anabolic and destructive mediators in osteoarthritis. Curr Opin Clin Nutr Metab Care 2000, 3:205-211.

27. Barnes PJ, Karin M: Nuclear factor-kappaB: a pivotal transcription factor in chronic inflammatory diseases. N Engl J Med 1997, 336:1066-1071.

28. van Beijnum JR, Buurman WA, Griffioen AW: Convergence and amplification of toll-like receptor (TLR) and receptor for advanced glycation end products (RAGE) signaling pathways via high mobility group B1 (HMGB1). Angiogenesis 2008, 11:91-99.

29. Pelletier JP, Martel-Pelletier J, Abramson SB: Osteoarthritis, an inflammatory disease: potential implication for the selection of new therapeutic targets. Arthritis Rheum 2001, 44:1237-1247.

30. Haywood L, McWilliams DF, Pearson Cl, Gill SE, Ganesan A, Wilson D, Walsh DA: Inflammation and angiogenesis in osteoarthritis. Arthritis Rheum 2003, 48:2173-2177.

31. Fuchs S, Skwara A, Bloch M, Dankbar B: Differential induction and regulation of matrix metalloproteinases in osteoarthritic tissue and fluid synovial fibroblasts. Osteoarthritis Cartilage 2004, 12:409-418.

32. Bondeson J, Wainwright SD, Lauder S, Amos N, Hughes CE: The role of synovial macrophages and macrophage-produced cytokines in driving aggrecanases, matrix metalloproteinases, and other destructive and inflammatory responses in osteoarthritis. Arthritis Res Ther 2006, 8:R187.

33. Rouhiainen A, Tumova S, Valmu L, Kalkkinen N, Rauvala H: Pivotal advance: analysis of proinflammatory activity of highly purified eukaryotic recombinant HMGB1 (amphoterin). J Leukoc Biol 2007, 81:49-58.

34. Palumbo R, Galvez BG, Pusterla T, De Marchis F, Cossu G, Marcu KB, Bianchi ME: Cells migrating to sites of tissue damage in response to the danger signal HMGB1 require NF-kappaB activation. J Cell Biol 2007 179:33-40.

35. Palumbo R, De Marchis F, Pusterla T, Conti A, Alessio M, Bianchi ME: Src family kinases are necessary for cell migration induced by extracellular HMGB1. J Leukoc Biol 2009, 86:617-623.

36. Hreggvidsdottir HS, Ostberg T, Wahamaa H, Schierbeck H, Aveberger AC, Klevenvall L, Palmblad K, Ottosson L, Andersson U, Harris HE: The alarmin HMGB1 acts in synergy with endogenous and exogenous danger signals to promote inflammation. J Leukoc Biol 2009, 86:655-662.

37. Hayashida K, Nanki T, Girschick H, Yavuz S, Ochi T, Lipsky PE: Synovial stromal cells from rheumatoid arthritis patients attract monocytes by producing MCP-1 and IL-8. Arthritis Res 2001, 3:118-126.

38. Mor A, Abramson SB, Pillinger MH: The fibroblast-like synovial cell in rheumatoid arthritis: a key player in inflammation and joint destruction. Clin Immunol 2005, 115:118-128.

39. Hatano $Y$, Kasama $T$, Iwabuchi $H$, Hanaoka $R$, Takeuchi $H T$, Jing $L$, Mori $Y$, Kobayashi K, Negishi M, Ide H, Adachi M: Macrophage inflammatory protein 1 alpha expression by synovial fluid neutrophils in rheumatoid arthritis. Ann Rheum Dis 1999, 58:297-302.

40. Akahoshi T, Wada C, Endo H, Hirota K, Hosaka S, Takagishi K, Kondo H, Kashiwazaki S, Matsushima K: Expression of monocyte chemotactic and activating factor in rheumatoid arthritis. Regulation of its production in synovial cells by interleukin-1 and tumor necrosis factor. Arthritis Rheum 1993, 36:762-771.

41. Schutyser E, Struyf S, Van Damme J: The CC chemokine CCL20 and its receptor CCR6. Cytokine Growth Factor Rev 2003, 14:409-426.

42. Chabaud M, Page G, Miossec P: Enhancing effect of IL-1, IL-17, and TNFalpha on macrophage inflammatory protein-3 alpha production in rheumatoid arthritis: regulation by soluble receptors and Th2 cytokines. $\mathrm{J}$ Immunol 2001, 167:6015-6020.
43. Koch AE, Kunkel SL, Burrows JC, Evanoff HL, Haines GK, Pope RM, Strieter RM: Synovial tissue macrophage as a source of the chemotactic cytokine IL-8. J Immunol 1991, 147:2187-2195.

44. Garcia-Vicuna R, Gomez-Gaviro MV, Dominguez-Luis MJ, Pec MK, GonzalezAlvaro I, Alvaro-Gracia JM, Diaz-Gonzalez F: CC and CXC chemokine receptors mediate migration, proliferation, and matrix metalloproteinase production by fibroblast-like synoviocytes from rheumatoid arthritis patients. Arthritis Rheum 2004, 50:3866-3877.

45. Ruth JH, Shahrara S, Park CC, Morel JC, Kumar P, Qin S, Koch AE: Role of macrophage inflammatory protein-3alpha and its ligand CCR6 in rheumatoid arthritis. Lab Invest 2003, 83:579-588.

46. Poole AR, Nelson F, Dahlberg L, Tchetina E, Kobayashi M, Yasuda T, Laverty S, Squires G, Kojima T, Wu W, Billinghurst RC: Proteolysis of the collagen fibril in osteoarthritis. Biochem Soc Symp 2003, 70:115-123.

47. Billinghurst RC, Dahlberg $L$, lonescu M, Reiner A, Bourne R, Rorabeck C, Mitchell P, Hambor J, Diekmann O, Tschesche H, Chen J, Van Wart H, Poole AR: Enhanced cleavage of type II collagen by collagenases in osteoarthritic articular cartilage. J Clin Invest 1997, 99:1534-1545.

48. Wu W, Billinghurst RC, Pidoux I, Antoniou J, Zukor D, Tanzer M, Poole AR: Sites of collagenase cleavage and denaturation of type II collagen in aging and osteoarthritic articular cartilage and their relationship to the distribution of matrix metalloproteinase 1 and matrix metalloproteinase 13. Arthritis Rheum 2002, 46:2087-2094.

49. Murphy G, Cockett MI, Stephens PE, Smith BJ, Docherty AJ: Stromelysin is an activator of procollagenase. A study with natural and recombinant enzymes. Biochem J 1987, 248:265-268.

50. Amos N, Lauder S, Evans A, Feldmann M, Bondeson J: Adenoviral gene transfer into osteoarthritis synovial cells using the endogenous inhibitor IkappaBalpha reveals that most, but not all, inflammatory and destructive mediators are NFkappaB dependent. Rheumatology 2006, 45:1201-1209.

51. Bondeson J, Lauder S, Wainwright S, Amos N, Evans A, Hughes C, Feldmann $M$, Caterson B: Adenoviral gene transfer of the endogenous inhibitor IkappaBalpha into human osteoarthritis synovial fibroblasts demonstrates that several matrix metalloproteinases and aggrecanases are nuclear factor-kappaB-dependent. J Rheumatol 2007, 34:523-533.

52. Miyazawa K, Mori A, Yamamoto K, Okudaira H: Transcriptional roles of CCAAT/enhancer binding protein-beta, nuclear factor-kappaB, and Cpromoter binding factor 1 in interleukin (IL)-1beta-induced IL- 6 synthesis by human rheumatoid fibroblast-like synoviocytes. J Biol Chem 1998, 273:7620-7627.

53. Stein B, Baldwin AS Jr: Distinct mechanisms for regulation of the interleukin-8 gene involve synergism and cooperativity between C/EBP and NF-kappa B. Mol Cell Biol 1993, 13:7191-7198.

54. Xing L, Remick DG: Promoter elements responsible for antioxidant regulation of MCP-1 gene expression. Antioxid Redox Signal 2007, 9:1979-1989.

55. Vincenti MP, Coon Cl, Brinckerhoff CE: Nuclear factor kappaB/p50 activates an element in the distal matrix metalloproteinase 1 promoter in interleukin-1beta-stimulated synovial fibroblasts. Arthritis Rheum 1998, 41:1987-1994.

56. Barchowsky A, Frleta D, Vincenti MP: Integration of the NF-kappaB and mitogen-activated protein kinase/AP-1 pathways at the collagenase-1 promoter: divergence of IL-1 and TNF-dependent signal transduction in rabbit primary synovial fibroblasts. Cytokine 2000, 12:1469-1479.

57. Firestein GS, Manning AM: Signal transduction and transcription factors in rheumatic disease. Arthritis Rheum 1999, 42:609-621.

58. Miyazawa K, Mori A, Miyata H, Akahane M, Ajisawa Y, Okudaira H: Regulation of interleukin-1beta-induced interleukin- 6 gene expression in human fibroblast-like synoviocytes by p38 mitogen-activated protein kinase. J Biol Chem 1998, 273:24832-24838.

59. Suzuki M, Tetsuka T, Yoshida S, Watanabe N, Kobayashi M, Matsui N Okamoto T: The role of p38 mitogen-activated protein kinase in IL-6 and IL-8 production from the TNF-alpha- or IL-1beta-stimulated rheumatoid synovial fibroblasts. FEBS Lett 2000, 465:23-27.

60. Pillinger MH, Rosenthal PB, Tolani SN, Apsel B, Dinsell V, Greenberg J, Chan ES, Gomez PF, Abramson SB: Cyclooxygenase-2-derived E prostaglandins down-regulate matrix metalloproteinase-1 expression in fibroblast-like synoviocytes via inhibition of extracellular signal-regulated kinase activation. J Immunol 2003, 171:6080-6089. 
61. Karin M: The regulation of AP-1 activity by mitogen-activated protein kinases. J Biol Chem 1995, 270:16483-16486.

62. O'Hagan RC, Tozer RG, Symons M, McCormick F, Hassell JA: The activity of the Ets transcription factor PEA3 is regulated by two distinct MAPK cascades. Oncogene 1996, 13:1323-1333.

63. Zhang $H G$, Wang $Y$, Xie JF, Liang $X$, Liu D, Yang P, Hsu HC, Ray RB, Mountz JD: Regulation of tumor necrosis factor alpha-mediated apoptosis of rheumatoid arthritis synovial fibroblasts by the protein kinase Akt. Arthritis Rheum 2001, 44:1555-1567.

64. El Mabrouk M, Sylvester J, Zafarullah M: Signaling pathways implicated in oncostatin M-induced aggrecanase- 1 and matrix metalloproteinase-13 expression in human articular chondrocytes. Biochim Biophys Acta 2007, 1773:309-320

65. Litherland GJ, Dixon C, Lakey RL, Robson T, Jones D, Young DA,

Cawston TE, Rowan AD: Synergistic collagenase expression and cartilage collagenolysis are phosphatidylinositol 3-kinase/Akt signalingdependent. J Biol Chem 2008, 283:14221-14229.

doi:10.1186/ar3124

Cite this article as: García-Arnandis et al:: High mobility group box 1 potentiates the pro-inflammatory effects of interleukin-1 $1 \beta$ in osteoarthritic synoviocytes. Arthritis Research \& Therapy 2010 12:R165.

\section{Submit your next manuscript to BioMed Central} and take full advantage of:

- Convenient online submission

- Thorough peer review

- No space constraints or color figure charges

- Immediate publication on acceptance

- Inclusion in PubMed, CAS, Scopus and Google Scholar

- Research which is freely available for redistribution

Submit your manuscript at www.biomedcentral.com/submit 